\title{
QUALITY OF SERVICE ORIENTED WEB SERVICE SELECTION: AN EVALUATION OF TECHNIQUES
}

\author{
Munjiah Nur Saadah, and Rigga Widar Atmagi \\ Department of Informatics, Faculty of Information Technology, Institut Teknologi Sepuluh Nopember, \\ Surabaya, 60222, Indonesia \\ E-mail: godofodin@gmail.com
}

\begin{abstract}
In service-oriented computing, web services are the basic foundation that aims to facilitate building of business application in a more flexible and interoperable manner for enterprise collaboration. One of the most promising advantages of web service technology is the possibility of creating added-value services by combining existing ones. A key step for composing and executing services lies in the selection of the individual service to use. Much attention has been devoted to appropriate selection of service functionalities, but also the non-functional properties of the services play a key role. A web service selection technique must take as much as possible the important influencing aspects into account to the selection process in order to minimize the selection efforts. This paper evaluates several web service selection techniques published in literature with the focus on their contributions to web service selection. The evaluation results can be used as a basis for improving web service selection techniques and then simplifying the selection tasks.
\end{abstract}

Keywords: Web services, QoS, Service Lifecycle Management, Web Service Broker, UDDI

\begin{abstract}
Abstrak
Dalam komputasi berorientasi layanan, layanan web adalah dasar pembangunan yang bertujuan untuk memfasilitasi pembangunan aplikasi bisnis dengan cara yang lebih fleksibel dan interoperable untuk kolaborasi perusahaan. Salah satu keuntungan yang paling menjanjikan dari teknologi web service adalah kemungkinan untuk menciptakan nilai tambah dengan menggabungkan layanan yang sudah ada. Sebuah langkah kunci untuk menyusun dan melaksanakan layanan terletak pada pemilihan layan-an individual yang akan digunakan. Banyak penelitian berfokus pada pemilihan fungsi pelayanan yang tepat, namun properti non-fungsional dari layanan yang memainkan peran kunci juga tetap diperhatikan. Sebuah teknik dalam menyeleksi layanan web harus mengambil sebanyak mungkin aspek penting yang mempengaruhi perhitungan terhadap proses seleksi dalam meminimalisir upaya seleksi. Penelitian ini mengevaluasi beberapa teknik seleksi layanan web yang dipublikasikan dalam literatur dengan fokus pada kontribusi mereka terhadap pemilihan layanan web. Hasil evaluasi dapat digunakan sebagai dasar untuk meningkatkan teknik pemilihan layanan web yang dapat menyederhanakan proses-proses seleksi.
\end{abstract}

Kata Kunci: Web services, QoS, Service Lifecycle Management, Web Service Broker, UDDI

\section{Introduction}

Web Service is a software component invoked over the Web via an XML message that follows the SOAP. It is powerful for organization and enter-prise-scales applications because it can pass through organizational boundaries [1,2]. Selection of appropriate web services is an important step in development of composite applications. Quality of Service (QoS) data characterizing nonfunctional properties of candidate web services are usually used in web service selection $[3,4]$.

There are various architectures and techniques that have been proposed from a very simple way until the latest ones that apply some formal or complex techniques.

This paper aims at evaluating several recent web selection techniques that have been published in literature. The evaluation focus is primarily on the capability of the techniques in supporting web selection. The initial results obtained by this evaluation can be used to indicate to what extends each approach has a capability to support web service selection. Consequently, the results can be used as a basis for improving the current techniques related to their support for web service selection. In addition, the evaluation results may also outline the desired criteria for a more holistic ap- 
proach in web service selection technique.

This paper is organized as follows: Section 2 provide a brief description on the state-of-the-art architecture and web service selection techniques. This section also presents the evaluation framework that is utilized to evaluate the techniques. Section 3 discusses the evaluation results as well as the rationale behind them. Finally, Section 4 presents the conclusion.

\section{Methods}

\section{Overview of Architecture and Technique}

Before discussing how to select web service, we should know how the service selection process. Before selecting a service, there is a process known as service discovery that was conducted by a service provider or broker. In this paper is called architecture. The development of architecture is accordance to the development of service selection techniques.

We reviewed about of recent papers relating architecture and web service selection topics. We resume here the architecture and web service selection techniques, which will be further evaluated.

\section{Web Service Selection Architectures}

According to Liavarasan [5] and Maximilian [6,7] research, architecture of web service selection that have been identified, namely customer as selector architecture, the QoS based Web Service Broker as selector, the QoS enhanced UDDI as selector, and the QoS based Delegation Web Service as selector.

The first architecture allows customers to choose a web service. The customer is the actual customer or web services using other web services. Selection mechanism handed over to customer.

The second architecture is the QoS based Web Service Broker as selector. The consumer will send a request that contains the desired functionality, selection preferences, and QoS requirements to the Web Service Broker. The Web Service Broker will provide the address of the appropriate web services so that consumers can directly access the address.

The third architecture is the QoS enhanced UDDI as selector. This method is similar to QoS based Web Service Broker as selector, but the Web Service Broker is replaced with a QoS enhanced UDDI registry.

The last architecture is the QoS based Delegation Web Service as selector. In this method there is a Delegation Web Service for each type of

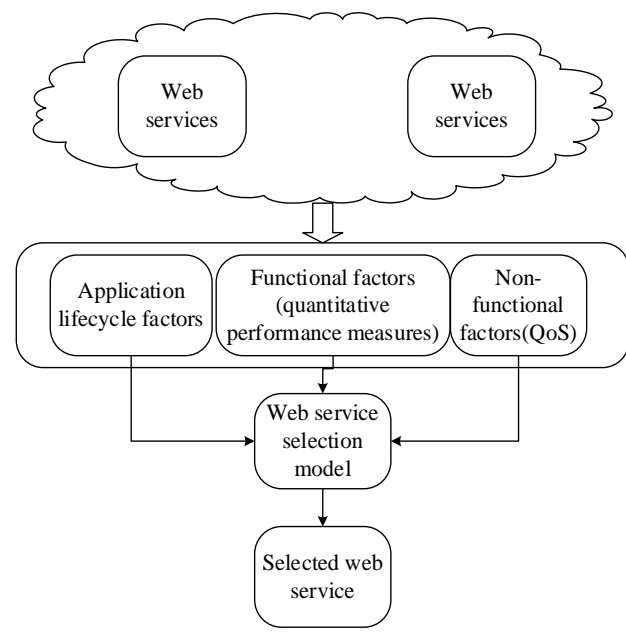

Figure1. Generic form of web service selection architecture.

web services aimed at simplifying the architecture and Delegation Web Service interface. In this method there is a Delegation Web Service for each type of web services aimed at simplifying the architecture and Delegation Web Service interface. The generic form of web service selection architecture is presented in Figure 1.

\section{Web Service Selection Techniques}

We reviewed about of recent papers relating web service selection topics. Based on them, we interested in three techniques that include specific subject, i.e. they put dynamic selection mechanism to perform web service selection. We resume here the web service selection techniques, which will be further evaluated.

Dynamic Selection of Web Services with Recommendation System (DSWS)

The proposed approach initiated by the service. The service will provide its requirement through the document semantics. These needs may vary according to the criteria of the service. Furthermore, service providers will register its services. Service will contain the QoS parameters and semantics of documents. This approach uses semantic matcher engine. This machine will match the consumer's request for documents semantics of services. Matching results are displayed in a list of recommended uses feedback recommendation engine. This recommendation engine learns through consumer feedback after using the service. [8], Manikrao [9] and Le-Hung Vu [10] proposed method where consumer will get a selection of web recommendation service in accordance with the previous consumer satisfaction ratings. 
26 Jurnal Ilmu Komputer dan Informasi (Journal of Computer Science and Information), Volume 7, Issue 1, February 2014

Agent-based Adaptive Dynamic Semantic Web Service Selection (AADS)

This approach focuses on both functional and non-functional service discovery and uses ontology concept to describe the unit of every QoS elements. This approach adopts an easier and practicable strategy to implement the reputation evaluation.

Jing li [14] propose this approach as a framework called an AADSS. This approach consists of two entities, namely agents designated provider for service providers and consumer agent designated for service consumers. Provider agent will provide the semantics of a service document, and then choose the service consumer agent. Consumers always select the service agent who has the best reputation for the consumer. This framework uses a combination of techniques to select and perform the rating service.

Service Adaptation Evaluation Based QSS Technique (SAQSS)

This method proposes a selection mechanism web service by utilizing the properties of semantic search and property quality of service. This method can work well when the composite service semantic logic turned into a new composite service semantic logic. Therefore, this method is classified as a selection method of semantic-aware. This method is also classified as QoS-aware selection me-

TABLE 1

\begin{tabular}{|c|c|c|}
\hline \multicolumn{3}{|c|}{ SIGNIFICAT CRITERIA } \\
\hline No & Specification & Descriptions \\
\hline 1 & QoS Modeling & $\begin{array}{l}\text { Specify the modeling langua- } \\
\text { ge used. }\end{array}$ \\
\hline 2 & QoS & Describe the Ontology of \\
\hline & Categorization & $\begin{array}{l}\text { QoS categorization with its } \\
\text { identification value. }\end{array}$ \\
\hline 3 & $\begin{array}{l}\text { Consumer } \\
\text { Preference }\end{array}$ & $\begin{array}{l}\text { Describe the varying prefe- } \\
\text { rences for the non-functional } \\
\text { criteria specified by the servi- } \\
\text { ce consumer }\end{array}$ \\
\hline 4 & $\begin{array}{l}\text { Aggregating the } \\
\text { evaluation of QoS }\end{array}$ & $\begin{array}{l}\text { This deals with aggregating } \\
\text { individual scores to gain a } \\
\text { final score for the service. }\end{array}$ \\
\hline 5 & Level Automation & $\begin{array}{l}\text { States the level of automation } \\
\text { mechanisms. The options are: } \\
\text { 1. A - Fully automated, } \\
\text { 2. SA - Semi automated, } \\
\text { 3. NA - Not applicable. }\end{array}$ \\
\hline 6 & $\begin{array}{l}\text { Agent } \\
\text { Involvement }\end{array}$ & $\begin{array}{l}\text { State whether agent participa- } \\
\text { tion is involved in the process } \\
\text { of service selection mechan- } \\
\text { ism. }\end{array}$ \\
\hline 7 & $\begin{array}{l}\text { Ranking } \\
\text { Algorithm }\end{array}$ & $\begin{array}{l}\text { A service rank is a quan- } \\
\text { titative metric that shows the } \\
\text { "importance" of a service } \\
\text { within the process of service } \\
\text { selection mechanism to rank } \\
\text { the services. }\end{array}$ \\
\hline
\end{tabular}

thod. QoS aware represent input, output and QoS criteria itself. This method implements the policies at each layer model. Policies consist of primitive symbol, action symbol and function symbol.

\section{Relationship between Architecture and Techni- ques}

Architecture and implementation of web service selection techniques have associated relationships. Architectures has different levels of complexity. It is also influence the selection of techniques used. If the web service selection techniques have a high complexity, then required architecture should also be able to support these techniques.

Usually architecture is built using a different platform. Platform differences also affect the election results web service. A platform architecture that is used only occasionally matches a particular technology. So that any kind optimal technique is, may not generate optimal results.

\section{Evaluation Framework}

Ladan [11] proposed service quality metrics that are simpler than those in the Yao Wang [12]. Yao wang's approach is complex and complicated method but has a very complete metrics. Ladan divides into service quality criteria such as performance, reliability, integrity, accessibility, availability, interoperability, and security. Criteria are referred to as service criteria. Satya [13] on his research has conducted an assessment of the various types of service selection method based on the quality of service. Assessment conducted by Satya generates a significant number of criteria.

\section{Evaluation of Technique}

This section describes a comparative evaluation of various QoS-based web service selection techniques. The evaluation focus is primarily on their capability to support QoS criteria. The initial results obtained from this evaluation can be used to indicate to which extent an approach satisfies some features in term of its support for web service selection.

\section{QoS Modeling}

DSWS using a model based on semantic QoS ontology. DSWS specifies the user requests a service description through DAML documents. DAML input obtained from a service WSDL document. QoS models are constructed is a multidimensional models.

AADS propose a modeling approach using semantic QoS ontology. QoS Ontologies to desc- 
ribe services and requests QoS constraints, adopt user feedback mechanism to get the dynamic QoS parameters. QoS models are constructed is not a multidimensional models.

SAQSS propose a modeling approach using semantic QoS ontology. QoS models are construc-ted is a multidimensional models. This model con-sists of property primitives for policy hierarchy and designed with four layers.

\section{QoS Categorization}

DSWS has extensible QoS model. The model depends on the variety of QoS criteria which the user input and a functional description of a service.

AADS has inextensible QoS model. The model describes a model which has the same rules so it can be matched well by the user agent and service providers.

SAQSS has inextensible QoS model. This model has four layers. Each layer describes its own QoS properties. The use of policies at differrent layers triggers the service adaptation and provides better service composition performance.

\section{Consumer Preferences}

DSWS, AADS and SAQSS accommodate user preferences to improve the accuracy of search results.

\section{Aggregating the evaluation of QoS}

DSWS deals with aggregating individual scores to gain a final score for the service. This approach provides value to each criterion that matches the selection process using semantic matcher engine. AADS deal with aggregating individual rating based feedback score to gain final score for the service. SAQSS do not aggregating individual score.
This approach utilize service adaptation algorithm if meet dissimilarity web service.

\section{Level Automation}

DSWS, AADS, and SAQSS are semi-automated because it needs consumer involvement. These approaches provide result based on consumer input. Human intervention may involve selecting QoS parameters used for selection, and changing preferences. But semi-automatic process involves little human intervention.

\section{Agent Involvement}

DSWS utilize semantic matcher machine as agent. It is core involvement in this approach. AADS did not utilize agent. Agent for AADS has been handled by architecture itself. This approach preferred using rating ranking table with point each web service to select a good one. SAQSS did not utilize agent because this approach using policy driven and semantic adaption algorithm to solve ranking algorithm.

\section{Ranking Algorithm}

DSWS deal with ranking algorithm. DSWS will sum the values of user satisfaction, functional suitability and compatibility the desired quality of service. The accumulation of value will be used to determine the rank a service

AADS deal with rating algorithm. AADS get the rate from user feedback after using the service. Service ranking is determined based on the accumulated rate from all the users.

SAQSS deal with policy driven ranking algorithm. Rank is determined by the agent based mo-del of web service. Compatibility value of between the required model and the proposed model determine ranking of a service. It can be

TABLE 2

RESUlt EVALUATION FEATURE WEB SERVICE SELECTION

\begin{tabular}{|c|c|c|c|}
\hline & DSWS & AADS & SAQSS \\
\hline QoS Modeling & semantic QoS ontology & semantic QoS ontology & $\begin{array}{l}\text { Semantic QoS } \\
\text { ontology }\end{array}$ \\
\hline QoS Categorization & inextensible QoS model & inextensible QoS model & $\begin{array}{l}\text { inextensible QoS } \\
\text { model }\end{array}$ \\
\hline Consumer Preferences & accommodate & $\begin{array}{l}\text { accommodate } \\
\text { aggregating individual }\end{array}$ & accommodate \\
\hline $\begin{array}{l}\text { Aggregating the evaluation of } \\
\text { QoS }\end{array}$ & $\begin{array}{l}\text { aggregating individual scores to } \\
\text { gain a final score for the service }\end{array}$ & $\begin{array}{l}\text { rating based feedback } \\
\text { score to gain final score } \\
\text { for the service }\end{array}$ & $\begin{array}{l}\text { do not aggregating } \\
\text { individual score }\end{array}$ \\
\hline Level Automation & Semi-automated & Semi-automated & Semi-automated \\
\hline Agent Involvement & Semantic matcher agent & Semantic matcher agent & Did not use agent. \\
\hline Ranking Algorithm & $\begin{array}{l}\text { Accumulate point ranking } \\
\text { algorithm }\end{array}$ & $\begin{array}{l}\text { Accumulate rating } \\
\text { feedback algorithm }\end{array}$ & $\begin{array}{l}\text { Comp ability policy } \\
\text { driven ranking } \\
\text { algorithm }\end{array}$ \\
\hline
\end{tabular}


28 Jurnal Ilmu Komputer dan Informasi (Journal of Computer Science and Information), Volume 7, Issue 1, February 2014

summarized on Table 3, result evaluation feature web service selection.

\section{Result and Analysis}

It can be concluded that most approaches contribute specific aspects to the overall picture of service selection, which requires methods for expressing user requirements, expressing service offerings and also the actual service selection method. Approaches tend to concentrate on specific of these areas and employ a variety of techniques to do that. It is more appropriate to make some suggestions for future developments in the area of selection approaches.

Important aspects that need addressing are powerful mechanisms to capture user requirements that are both user friendly and also expressive enough to capture large numbers of preferences and the logical relations between preferences. One aspect that falls into this area is the measuring of weights. Also, in the process of capturing the needs of users, their preference of data, research has to show interest and capability to automatically capture this, to reduce the burden on the user part, and to react to changes in circumstances automatically.

Modeling conducted by the three selection techniques web service has been very good. Semantic ontology was chosen because it is able to accommodate your searching based on the context. Currently, the search based on context is recognized well than searches based on the syntax. Semantic models also have benefits for recommendation web service case.

In the overall results of modeling web service, it is very difficult to determine which web service will be selected. The current method is a method frequently used weighting. Weighting method is used because it is considered to represent the logical priority of the user. Each model has the property that the web service will be calculated level of similarity to the model the user desires. Accumulated value determines the election of a web service.

There are other weight calculation techniques. There is an additional property which is input user feedback. The result is the best of the quality and best of the views of users.

Each approach has its advantages and disadvantages. Approach that uses a point accumulation or categories of feedback is very dependent on time. Earlier and present users maybe obtain selection of different web service. This case is different with the matching web service template.
By performing matching, a web service that will be selected is equal.

Web service matching approach is rigid templates. Web service template changes performed manually. Unlike the accumulation which is dynamic in terms of selection.

Selection-related services in a way that could result in selection an appropriate and satisfactory results. Ways to improve the accuracy of the results of the selection is to modify the service selection approach or by combining several techniques. Learning the merits of multiple algorithms to conduct algorithm fusion is an important way to improve the performance of service selection algorithm, there is still much work to do.

Architecture where the selection of services does provides different results for each implementation. For example, architecture involving consumer intervention produces different results with the implementation of the architecture without consumer intervention. Sometimes with the involvement of consumer intervention, the results are not optimal, but appropriate and highly satisfying con-sumer.

\section{Threat to Validity}

First, the sources that are used to evaluate the techniques are mainly from the published research papers, especially from the international journals and or the conference proceedings. The papers usually contain brief and compressed information in that some other information probably were disappeared related to the long version one, i.e. dissertation report, or technical report. Therefore the justifications are made from the concise information. Justifications are performed without any formal methodology. We use our comprehension from reading the papers and concluding the result based on our understanding and intuition. However, the initial result presented in the evaluation can be very useful to perform further and deeper evaluation of the techniques for future improvement, and also to welcome any open discussions.

\section{Conclusion}

In this paper, we have presented the evaluation of state-of-the-art web selection techniques, especially in the context of web selection techn-ique. We have evaluated the techniques using criteria QoS web service framework in brief way, especially in their support for web service selection schemes. The results showed us that so far, there is no techniques fully satisfied all of the requirements and criteria QoS based web service selec- 
tion. This means that much work have to be done to achieve the better techniques in the future.

Recommendations for improvement of web service selection technique are performing a combination of several techniques. There are two general phases before selecting a web service, the service discovery and service selection. The hypothesis proposed is, if each phase using the most optimal method then we will get the best web service and satisfy user requirements.

\section{References}

[1] Xin Dong Alon Halevy Jayant Madhavan Ema Nemes Jun Zhang "Similarity Search for Web Services.” Proceedings of the 30th VL-DB Conference, Toronto, Canada, 2004

[2] Le-Hung Vu, QoS-based Service Selection and Ranking with Trust and Reputation Management, EPFL, Switzerland.

[3] Bonders, M. and Grabis, J., A Holistic Method for Selecting Web Services in Design of Composite Applications. Institute of Inform-ation Technology, Riga Technical Universi-ty, 1.

[4] Kokash, Natallia. "A service selection model to improve composition reliability." International Workshop on AI for Service Composition, University of Trento. 2006..

[5] Egambaram, IIavarasan, G. Vadivelou, and S. Prasath Sivasubramanian. "Qos based web service selection." The International Conference on Computing, Communications and Information Technology Applications (CCITA-2010). 2010.

[6] E. Maximilien and M. Singh. "Towards Autonomic Web Services, Trust and Selection.” ICSOC'04 pages 212-221, November 2004
[7] Jyoti Jakhar," A Test Based Web Service Selection Approach”, In International Journal of Research and Reviews in Computer Science (IJRRCS), 2011.

[8] Konstantinos Tserpes, “A Recommender Mechanism for Service Selection in ServiceOriented Environment”, In Future Generation Computer System-Sciencedirect, 2011.

[9] Manikrao, Umardand Shripad, and T. V. Prabhakar. "Dynamic selection of web services with recommendation system." International Conference on Next Generation Web Services Practices (NWeSP'05). IEEE, 2005.

[10] Vu, Le-Hung, Manfred Hauswirth, and Karl Aberer. "QoS-based service selection and ranking with trust and reputation management." OTM Confederated International Conferences" On the Move to Meaningful Internet Systems". Springer Berlin Heidelberg, 2005.

[11] Mohamad Ibrahim Ladan, Ph.D.,” Web Services Metrics: A Survey and A Classification”, International Conference On Network And Electronics Engineering, Singapore, 2011.

[12] Wang, Yao, and Julita Vassileva. "Toward trust and reputation based web service selecti-on: A survey." International Transactions on Systems Science and Applications 3.2 (2007): 118-132.

[13] M. Sathya, M. Swarnamugi, P. Dhavachelvan \& G. Sureshkumar," Evaluation Of Qos Ba-sed Web-Service Selection Techniques For Service Composition”, In International Jour-nal Of Software Engineering (IJSE), Volume (1): Issue (5) , 2011.

[14] Jing Li, Dianfu Ma, Lusong Li, Hong Zu,” AADS: Agent-Based Adaptive Dynamic Semantic Web Service Selection”, In 4th International Conference on Next Generation Web Services Practices, 2008. 